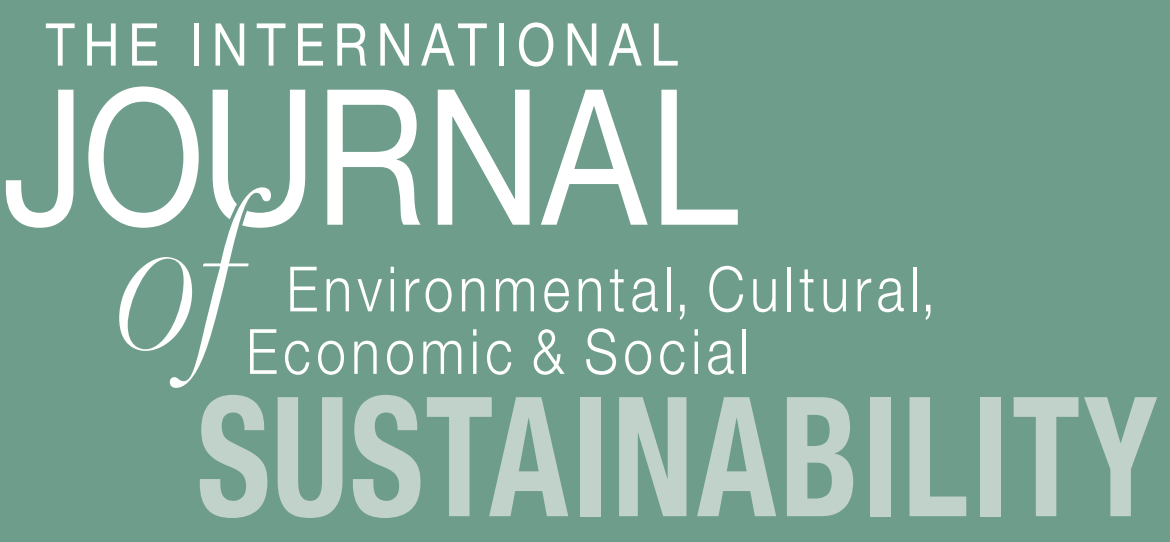

Volume 7, Number 3

Learning for Change: Cross-disciplinary Postgraduate Programmes in Sustainability

David Grierson and Claire Hyland 
THE INTERNATIONAL JOURNAL OF ENVIRONMENTAL, CULTURAL, ECONOMIC AND SOCIAL SUSTAINABILITY

http://www.Sustainability-Journal.com

First published in 2011 in Champaign, Illinois, USA

by Common Ground Publishing LLC

www.CommonGroundPublishing.com

ISSN: $1832-2077$

(C) 2011 (individual papers), the author(s)

(c) 2011 (selection and editorial matter) Common Ground

All rights reserved. Apart from fair dealing for the purposes of study, research, criticism or review as permitted under the applicable copyright legislation, no part of this work may be reproduced by any process without written permission from the publisher. For permissions and other inquiries, please contact

<cg-support@commongroundpublishing.com>.

THE INTERNATIONAL JOURNAL OF ENVIRONMENTAL, CULTURAL, ECONOMIC AND SOCIAL SUSTAINABILITY is peer-reviewed, supported by rigorous processes of criterion-referenced article ranking and qualitative commentary, ensuring that only intellectual work of the greatest substance and highest significance is published.

Typeset in Common Ground Markup Language using CGPublisher multichannel typesetting system

http://www.commongroundpublishing.com/software/ 


\title{
Learning for Change: Cross-disciplinary Postgraduate Programmes in Sustainability
}

\author{
David Grierson, University of Strathclyde, Scotland, UK \\ Claire Hyland, University of Strathclyde, Scotland, UK
}

\begin{abstract}
Through connecting the local and global, higher education institutions play a vital role in addressing social, environmental and economic challenges and ultimately achieving a sustainable future. New Horizons: Responding to the Challenges of the 21st Century (Scottish Government, 2008), outlines the contributions which Scottish universities should make to the economy, culture and society, and to the political priorities of the Scottish Government. Learning for Change: Scotland's Action Plan for the Second Half of the UN Decade of Education for Sustainable Development (Scottish Government, 2010) examines progress to date and sets out the actions that higher education institutions have committed to undertaking in the second half of the decade and beyond. These two important documents provide the context for work that has taken place at the University of Strathclyde in response to the challenges set out within them. The University of Strathclyde has been ranked first in the Engineering Education for Sustainable Development (ESD) Observatory Report 2008 and plans to build on this success. The challenges presented by Sustainable Development are inherently holistic, demanding equal responses from all disciplines and this requires the development of a framework for Universitywide, cross disciplinary teaching. This paper describes work that has taken place within the University to develop a new university-wide, multi-disciplinary, Strathclyde Masters programme in Sustainability (SMS) aimed at articulating a framework for integrating flagship postgraduate courses \& classes, sustainability literacy, skills training workshops and subsequent continuing professional development courses. Conclusions are presented from the three main bodies of work involved: a review of current thinking in ESD; a multi-stakeholder consultation process involving students, academic and professional services staff within the university, and external stakeholders, and the creation of a Sustainability Map detailing current postgraduate provision of ESD at the University.
\end{abstract}

Keywords: Education for Sustainable Development, Scottish Universities, Postgraduate Programmes

\section{Introduction}

$\mathrm{T}$

HIS PAPER DESCRIBES the various ways in which the University of Strathclyde is responding to challenges set out by the Scottish Government, with particular focus on research undertaken during the development of a framework for a new pan-university Strathclyde Masters programme in Sustainability (SMS). After introducing the SMS vision the paper discusses the crucial role that universities play in addressing the social, environmental and economic challenges faced by the global community. Two important documents, New Horizons: responding to the challenges of the 21st century (2008) and Learning for Change: Scotland's Action Plan for the Second Half of the UN Decade of Education for Sustainable Development (2010) produced by the Scottish Government, detail the changes that Scottish Universities are expected to make in order to deal with these challenges. A summary of these documents provides the context for work that has taken place

The International Journal of Environmental, Cultural, Economic and Social Sustainability C $O M M O N$ Volume 7, Number 3, 2011, http://www.Sustainability-Journal.com, ISSN 1832-2077 
at the University of Strathclyde in response to the challenges set out within them. A brief description of Strathclyde's current achievements in ESD precedes a more detailed exploration of how the current SMS initiative plans to build on these, by developing a new universitywide, multi-disciplinary, Strathclyde Masters programme in Sustainability (SMS). Conclusions from the research undertaken are presented in three main stages including (i) a review of current thinking in ESD, (ii) a structured consultation programme and (iii) the creation of both a current and future 'sustainability map' showing postgraduate provision of ESD within the University. The review of current thinking in ESD uses literature and case studies detailing initiatives to embed ESD within Higher Education Institutions, and describes how these have been used to structure and inform the following stages of the research. The paper then details the conclusions drawn from the initial multi-stakeholder consultation process and describes how these relate to the Scottish Government's objectives. The model 'Sustainability Map' is presented, offering an overview of postgraduate provision of ESD within the institution as a whole, based on information gathered detailing courses offered and contributing departments. The future 'Sustainability Map' describes in a simple diagrammatical format, how the SMS would sit within the university structure. In addition, a draft SMS Programme Structure details how the research outcomes can be integrated within the curriculum and offers a basis for future consultation and development.

\section{SMS Vision}

The University of Strathclyde aims to promote and undertake a visionary programme of cross-disciplinary research and postgraduate teaching in sustainable development, relevant for Strathclyde Graduates and Degrees for the 21st Century and in support of the 'One Strathclyde' approach. The Vision of the University as an international technological university and the Strategic Plan for the University (2011-2014) provide the context for the development of this proposed multi-Faculty initiative, which will build on the existing highquality provision of ESD within the University. The SMS project aims to articulate a framework for integrating flagship postgraduate courses \& classes, sustainability literacy \& skills training workshops, and subsequent Continuing Professional Development (CPD) courses. The new pan-university SMS programme will champion critical thinking in sustainability while promoting interdisciplinary working in collaboration with business and industry. Increased internationalisation and an enhanced student learning experience are main objectives for the programme. Central to this is the development of networks and mechanisms for effective knowledge exchange, innovation and engagement with stakeholders. The aim of the first stage of the proposal is to define a clear structure for the integration of postgraduate provision within the sustainability area involving input from relevant stakeholders, and provide an integrated framework for University-wide educational activities in the sustainability area that will enhance the learning experience of students. This vision has come as a direct response to the need for universities to contribute to the ESD agenda, and responds directly to the objectives set out by the Scottish Government for universities, both of which are discussed in the following sections. 


\section{Importance of Universities \& ESD}

The period 2005 - 2014 has been declared as the United Nation Decade of Education for Sustainable Development (UNDESD, Johannesburg Summit, 2002). The goal of DESD is to integrate the principles, values, and practices of sustainable development into all aspects of education and learning. The need for ESD has now been recognised by many national and international education and government bodies (UNESCO, Nov 2008). In particular, two main Higher Education funding bodies, the Scottish Funding Council and the Higher Education Academy have incorporated ESD as an integral part of their strategic priorities (SFC, 2009; HEA, Aug 2009). The report Education for Sustainable Development in the $U K$ in 2010 describes ESD as:

"fundamentally about values, with respect at the centre: respect for others, including those of present and future generations, for difference and diversity, for the environment, for the resources of the planet we inhabit."

(UNESCO, Sep 2010)

It further expands on this definition describing the concerns of ESD as: interdisciplinary and holistic, values-driven, fostering critical thinking and problem solving, multi-method, participatory, applicable to daily life whether personal or professional and locally relevant in terms of context (UNESCO, Sep 2010).

The United Nations advocate that higher education will be key to changing and reshaping society's attitude towards achieving a sustainable future. As centres of knowledge production and exchange, and training provision, universities are well positioned to connect the local (through close links with neighbouring communities, business, and industry) and the global (through associations with international learning and research networks). In this way universities have considerable access to, and influence over, human development processes. "Human development is about...creating an environment in which people can develop their full potential and lead productive, creative lives in accord with their needs and interests" (UNDP, 2007). A number of well known global frameworks and initiatives support these values including The Millennium Development Goals, the UN Kyoto Protocol, and the UNESCO Decade of Education for Sustainable Development (2005 - 14). However these frameworks, of themselves, do not provide a guarantee of positive change. Progress towards some of the targets enshrined within them has been slow or nonexistent. The challenges involved are massive and cannot be underestimated. Huge disparities between the developed and developing nations are at the heart of this.

UNESCO (2005) contends that education will play a vital role in sharing, applying and creating knowledge in a globalizing world. Universities will fuel the driving forces of transformation towards a global knowledge society. They have the capacity to steer and eventually correct the direction of (negative - unsustainable) trends within globalisation. The process of sustainable development requires that we all attain the skills needed to handle the complex challenges of change and uncertainty, and the ability to communicate with a large number of stakeholders. In this sense universities are working at different levels to become engines of wider societal change - to address both global and local needs and priorities. The contribution of universities to the sustainability agenda is being expressed in transdisciplinary research and knowledge exchange activity and more recently embedded within 
teaching and learning provision. Universities have a dual responsibility - to provide graduates with the attitude, knowledge and skills to lead this process, while also developing the knowledge to support research on sustainable development $\&$ share knowledge with external partners. In responding to this challenge, universities are developing not only their capability to articulate a vision of a better world (and solutions to today's problems) but also their willingness and ability to reach out towards an unknown future by working in partnership with many others, both locally and globally.

\section{Scottish Government's Objectives for HEl's}

The Scottish Government has recently published two important documents outlining new objectives for Scottish Higher Education Institutions (HEI's). New Horizons: Responding to the Challenges of the 21st Century (Scottish Government, 2008), outlines the contributions which Scottish universities should make to the economy, culture and society, and to the political priorities of the Scottish Government. Learning for Change: Scotland's Action Plan for the Second Half of the UN Decade of Education for Sustainable Development (Scottish Government, 2010) examines progress to date and sets out the actions that higher education institutions have committed to undertaking in the second half of the decade and beyond. Both of these documents are summarised within this paper and key objectives highlighted such as the need to: provide more relevant academic courses and modules responding to the changing skills needs of Scotland's workforce by integrating ESD into the curricula; enhance links with business and local communities, compensating for lack of R \& D undertaken by businesses in order to boost innovation and the economy; increase international student numbers, specifically sustaining growth in postgraduate student numbers; encourage students to stay after graduation, and provide more flexible learning provision for a changing student profile.

Scotland has introduced the world's most ambitious climate change legislation (Climate Change Scotland Act 2009) aiming to reduce greenhouse gas emissions by $80 \%$ by 2050 , providing an entirely new legislative backdrop to the second half of the UN Decade of ESD. Similarly to the rest of the world Scotland will have to make dramatic changes in order to adapt to face predicted environmental challenges such as depleting natural resources and changing weather patterns. Universities have a crucial role to play not only in the development of new technologies to minimise all aspects of climate change and environmental damage, but also in ensuring existing technologies are used to best advantage and in raising public awareness and changing behaviour patterns. It is emphasised that sustainable development encompasses more than just climate change and the environment, and that a sustainable future will require widespread understanding and cultural change. ESD is key to achieving this and depends upon equipping people with the skills needed in order to make important complex decisions, taking into account social, environmental and economic factors alike. The current knowledge-based economy depends on skills such as creativity, flexibility, adaptive capacity, the ability to work in complex teams across disciplines and the ability to practically employ these skills to best effect. Universities should respond to the changing skills needs of Scotland's workforce by integrating ESD into the curricula, ensuring that the entire educational experience contributes to the development of an individual's sustainability literacy and citizenship skills. This will also require the provision of new more relevant academic courses 
and modules. In order to do this, it is recognised that universities should have access to the highest quality materials, advice and support.

Both documents acknowledge that HEI's, as autonomous bodies, have a positive influence on society in both cultural and economic terms. HEI's perform a fundamental role in the wealth production and economics of the country, equal to that of a $£ 2$ billion plus business, and are major providers of human capital. It is envisaged that universities use this key role in order to develop knowledge and understanding of sustainable development. As the country's main centres of research and development ( $R$ \& D), universities can enhance links with business in order to compensate for low levels of R \& D currently undertaken by Scottish firms, the majority of which are small and medium sized enterprises (SME's). This will help to make the economy more innovative and improve Scotland's capacity to face increasing international competition on innovation and technology presented by emerging nations. It is hoped that strengthening relationships between universities and businesses will also aid graduate employability. As universities aid the economy by delivering new knowledge which creates additional wealth, businesses will reciprocate with greater investment. Scottish universities should therefore endeavour to foster relationships and improve knowledge transfer between themselves and the micro, small and medium sized business base. In addition, universities are required to demonstrate that any funds received from the Scottish Government are used for activities aligned with the Scottish Government's Purpose, its economic and skills strategies and its other policy frameworks.

Universities are a prime earner of foreign currency through recruitment of international students, successful biding for research grants and links with international businesses. Scotland's universities are among the most international in the world with one fifth of the student population coming from outside to study. Many will remain in Scotland after completion of their studies, increasing the available pool of human capital and helping to counteract demographic change. International relationships between universities are important in promoting the country's national identity. The sharing of knowledge at in international level is crucial for research and innovation to progress at a high level. To this end universities should aim to increase international student numbers and work to increase employment opportunities that will encourage students to stay in Scotland after graduation. It is acknowledged that universities will require sufficient funding to ensure sustained growth in postgraduate numbers.

More flexible learning provision will be crucial in order to provide for a changing student profile. The majority of the workforce will be expected to change career direction several times in their lives and will reenter education to up-skill or re-skill. In addition, changing birth rates, an ageing population and more varied working practices will result in a move away from the necessity of full-time, traditionally taught courses to a need for more parttime, flexible provision delivered through a variety of means. Access to higher education in later life is also important in order for those who do not have the chance earlier in life to be able to return. This can be achieved through active engagement between employers and universities to ensure that graduates are equipped with the most appropriate skills and that employers have an active role to play in the curriculum content and delivery. Universities should also enhance existing links and work to create more links with local communities, helping to join local communities with local networks and in turn instilling students with a greater sense of their place in the local community and the wider world. 


\section{University of Strathclyde's Response to Government Objectives}

With regards to ESD, the University of Strathclyde has national and international leading research opportunities in a number of sustainability-related areas and has been at the forefront of environmental education, and interdisciplinary teaching in sustainability-related areas since the 1990s. As a result of these activities and planned initiatives such as the SMS the University has recently been recognised as a leading European institution in addressing issues of sustainable development. Strathclyde has been ranked first of 56 technological universities in the recent European sustainability rankings by the Engineering Education for Sustainable Development Observatory Report 2008 (EESD, 2008). The report identifies the extent to which sustainability is embedded in research, undergraduate and postgraduate education within the curricula, and within approaches to institutional management. The University of Strathclyde is the only university thus far to have achieved a score above 9, placing the university in the 'inspiration' category. The breakdown of the scoring system is shown in the table below.

Table Showing Breakdown of Scoring System used for each University (EESD, 2008)

\begin{tabular}{|l|l|l|l|l|l|}
\hline \multicolumn{7}{|c|}{ Indicator Score } \\
\hline Research & $\begin{array}{l}\text { Undergraduate } \\
\text { Education }\end{array}$ & $\begin{array}{l}\text { Postgraduate } \\
\text { Education }\end{array}$ & $\begin{array}{l}\text { Embedded } \\
\text { Education }\end{array}$ & $\begin{array}{l}\text { In-house } \\
\text { EMS }\end{array}$ & $\begin{array}{l}\text { Total } \\
\text { Indicator }\end{array}$ \\
\hline $0-2$ & $0-2$ & $0-2$ & $0-2$ & $0-2$ & $0-10$ \\
\hline
\end{tabular}

A major contributor to this achievement was the Sustainable Engineering programme, launched in 1999, which integrates MSc courses from across the various engineering disciplines. Graduates gain advanced technical and 'soft skills' training to meet Engineering Council requirements to support chartered engineer status. A major benefit is the opportunity for students to complete a group project for an industrial client with input from different disciplines. This provides a vehicle for industrial involvement and knowledge exchange, with findings disseminated at an annual conference. There is widespread use of online learning in the classes where groups of students from different disciplines and cultures have the chance to debate and discuss issues related to the learning resources provided in the class. Over 500 students have graduated from the SE programme with a variety of attributes, including skills dealing with issues of complexity, enhanced communication and networking. Along with knowledge of sustainability, students foster a social and political agency and group work gives them an appreciation of the role of others within an interdisciplinary working environment (CSF, 2009). This innovative approach to the sustainable development agenda ensures students receive advanced engineering training, and gain invaluable insights into how to address some of the issues that companies face when integrating sustainable practices into their businesses. The SMS project aims to build on this success to provide a framework within which interdisciplinary and interfaculty learning and teaching can take place, developed in collaboration with key stakeholders and with the Scottish Government's objectives as key factors. 


\section{Current Thinking in ESD}

An extensive review of current thinking in ESD was undertaken drawing on common aspects of various case studies relating to initiatives aimed at embedding ESD within the curriculum. This proved to be a valuable tool used in the development of other research activities, such as the multi-stakeholder consultation process and creation of a Sustainability Map. This section draws on the relevant key issues and explains the manner in which they have influenced the SMS project.

The Higher Education Academy emphasises that a rigorous process of consultation offers a vital tool in module, course, and programme review and in supporting curriculum renewal and development (HEA, Apr 2008). ESD may be interpreted in a variety of ways according to regional, national and local differences and it is therefore imperative to involve a wide range of stakeholders in the development and implementation of any ESD related framework (UNESCO 2009). An important first step in developing the SMS was to establish multistakeholder consultation groups which included, all postgraduate students within the university; SMS Faculty representatives nominated by the Deans to represent each Faculty; university management and professional services, as well as external stakeholder organisations nominated to represent each faculty and led by a smaller SMS External Working Group. Identified objectives were to define: discipline related demands of sustainable development and generic skills required to deal with these demands; the best approach to embed ESD within university-wide integrated provision; requirements for curriculum renewal for ESD; appropriate flexible teaching delivery methods; key attributes for new graduates, and stakeholder willingness to embed ESD. The methodology and outcomes of the consultation process are detailed in the International Journal of Interdisciplinary Social Sciences (Grierson, D; Hyland, C, 2010).

It was also highlighted that an important preliminary step in establishing an appropriate approach to embed ESD within an institution is to analyse the level of provision within the existing curriculum through a process of review and consultation. It is imperative to establish which areas work well and already incorporate ESD, or can be easily adapted to incorporate ESD within a structured process of curriculum renewal. While there exists significant variation in practice across many subject areas, many of the objectives and pedagogies of ESD are similar irrespective of subject area (HEA, Jan 2006). Provision of ESD is in many cases already part of the formal education curriculum, but not identified as such (UNESCO 2005). The Higher Education Academy's Review of Education for Sustainable Development in Scotland (HEA, Feb 2009) found that there has been a gradual penetration of sustainability issues into a wide spectrum of disciplines taking shape in formal 'flagship' courses, and a gradual embedding of these issues into the curriculum. ESD has filtered through disciplines such as environmental sciences and architecture, where a specific concern for a more efficient use of natural resources has had an impact on professional regulations and accreditation requirements, and is now emerging in many other subject areas. However in 2010 the integration of ESD into some courses is still slow and in some cases non existent when compared to sectors such as construction which has made significant progress (UNESCO, Sep 2010). In order to identify appropriate teaching methods it is important to establish the relevant discipline-related concepts in sustainability and evaluate current course provision (UNESCO 2009). As such, all Departments within the University have been asked to contribute to the creation of a "Sustainability Map" which details postgraduate provision of ESD within the university. 
The need for increased provision of interdisciplinary teaching and research opportunities was reinforced throughout the case studies reviewed. In order to deal with issues of sustainability it is necessary to be equipped not only with a strong technical knowledge and the ability to work in a team, but also the necessary vocational and social skills, and new learning processes and educational methodologies should be developed in order to achieve this (UNESCO 2009). Identifying and setting thematic priorities in the curriculum, while at the same time emphasising a holistic approach, can be complex. Case studies have suggested that a shift is needed from more traditional teaching delivery methods to problem-based learning. The UNESCO Review of Contexts and Structures for Education for Sustainable Development 2009 (UNESCO 2009) has acknowledged increased networking at a local, national and international level to be crucial. Furthermore it has called for multi-stakeholder dialogue between individuals and organisations representative of all dimensions of ESD to be strengthened during the remaining half of the DESD. As indicated in the Higher Education Academy's report, Sustainable Development in Higher Education, Current Practice and Future Developments (HEA, Jan 2006), most subject centres found that this engagement could be achieved either through real-world, project-based work, field work, site visits, case studies and / or by asking students to apply their discussion of literary texts to other areas of their lives. Examples included the use of a Virtual Learning Environment (VLE) as a flexible teaching tool, and the direct involvement of industry through engagement in providing and helping with supervision of 'live' projects. The direct input of industrial and practice-based representatives within learning modules also supported wider engagement. Relationships between teachers, researchers, industry and government can have benefits for all parties, and help support research / teaching linkages. An estimated 50,000 new jobs will be created in the green sector in Scotland in the coming years (UNESCO, Sep 2009). This highlights the opportunity to enhance graduate employability by ensuring the skills gap in these sectors is met through the direct involvement of external stakeholders in curriculum development. The following section details the consultation process which has explored the required graduate skills and attributes necessary in order to deal with the demands of sustainable development as well as favoured approaches to helping students develop these skills and how these can be embedded within the curriculum. It is envisaged that through multistakeholder involvement in these key areas, opportunities for multidisciplinary, live, projectbased learning and research, and knowledge exchange activity will be enhanced and strongly supported both externally and within the University itself. The following section summarises the main conclusions of the consultation process and relates these to the Scottish Government's objectives.

\section{Multi-stakeholder Consultation Findings}

Through the multi-stakeholder consultation process it was confirmed that sustainable development is a priority for both students and employers and that both would like to see more emphasise placed on this agenda. It was acknowledged that universities and higher education institutions, as centres of knowledge production \& exchange, have the ability to lead the way in response to the sustainable development agenda, and that collaboration between universities, government and industry is needed. The questionnaire exposed the large international postgraduate community which already exists at the university and this will be encouraged to grow through the provision of more flexible learning and relevant courses de- 
veloped in collaboration with external organisations leading to enhanced prospects of employment. This responds directly to the Scottish Government objective to increase income through international student recruitment and also enhance international academic relations. The large majority of students said they would consider a future employer's social and environmental responsibility while seeking employment. The external organisations concurred with this stating that they would consider a graduate's knowledge and skills in sustainable development when recruiting. While the SMS initiative has emerged initially from concerns within architecture and engineering the view was upheld that the challenges of SD require responses from all disciplines and professions represented within the institution.

It was reinforced that an understanding of the complex issues involved in SD and interdisciplinary skills are core requirements. The large majority of students feel that the chance to interact with other disciplines would be beneficial to their studies. A broad understanding of the range of factors involved in SD along with an ability to make strategic decisions based on this information is essential. Communication and networking skills were deemed to be equally as important as technical knowledge and teaching through skills training workshops and live projects in collaboration with industry are favoured methods of instilling these skills. The idea of introducing generic modules within flagship courses was well received by SMS Faculty Representatives and various suggestions offered as to how the structure of the SMS could be developed. Knowledge of sustainability can be instilled through generic modules which allow students of different disciplines to exchange ideas and work at a similar level. Difficulties occur when addressing more specific subject areas as students from different disciplines have varying levels of expertise and both should benefit from the experience. Interdisciplinary group projects allow students to gain practical interdisciplinary skills while at the same time developing technical skills in their specific area of study. The increased involvement of external organisations in the development of the curriculum and the setting of real projects and research objectives should help to enhance links with business and local communities and foster future research collaboration opportunities.

It was acknowledged that collaboration with industry brings benefits to all parties and live projects set by industry should be enhanced through a more structured form of communication between the student, industrial support and academic support. Students cited the chance of enhancing employability as the most popular reason for selecting a particular course or field of study, reinforcing the importance of close consultation with external stakeholders when identifying necessary graduate attributes. Course accreditation by professional bodies should also be taken into account when developing the academic content of the SMS. It was agreed in principle that the Strathclyde Masters programme in Sustainability (SMS) is an initiative that requires university-wide collaboration. It was acknowledged that continued consultation with all stakeholders will be important to the success of the initiative and should ensure benefit for all participants. Existing staff-student liaison structures set up to support undergraduate courses could be adapted for postgraduate level in order to support this continuing consultation process. Through continued consultation with all stakeholder groups new courses and modules can be developed to respond to the changing skills needs of Scotland's workforce and provide more flexible learning provision for a changing student profile. 


\section{Sustainability Map}

A Sustainability Map is in the process of being created which details postgraduate ESD activity across the university and is further detailed in the International Journal of Interdisciplinary Social Sciences (Grierson, D; Hyland, C, 2010). A diagram of the Sustainability Map as viewed in Figure 1(a) shows a stronger presence of ESD within the Faculty of Engineering and diagrams the Sustainable Engineering Programme which provides a framework for interdisciplinary education within the faculty. A greater strength in ESD within the engineering disciplines is to be expected and is concurrent with the review of current thinking in ESD, which acknowledged ESD to be stronger in certain disciplines than others. Across the university there was found to be a strong presence of external links with other HEI's and industry, as well as internal collaboration with cross-departmental and cross-faculty courses sharing modules. A future Sustainability Map as presented in Figure 4(b) shows a more even distribution across all subject disciplines and individual Sustainability 'packages' provided by each Faculty. It is envisaged that these sustainability packages could be based on an amended version of the current Sustainable Engineering package. Three main levels of activity are shown: the SMS university-wide programme providing optional SD modules \& literary / skills workshops, SD industry-based interdisciplinary group projects and subsequent CPD events; Individual Faculty packages offering optional modules, group projects and subsequent CPD events; and finally Discipline-specific courses, modules \& individual projects / dissertations.
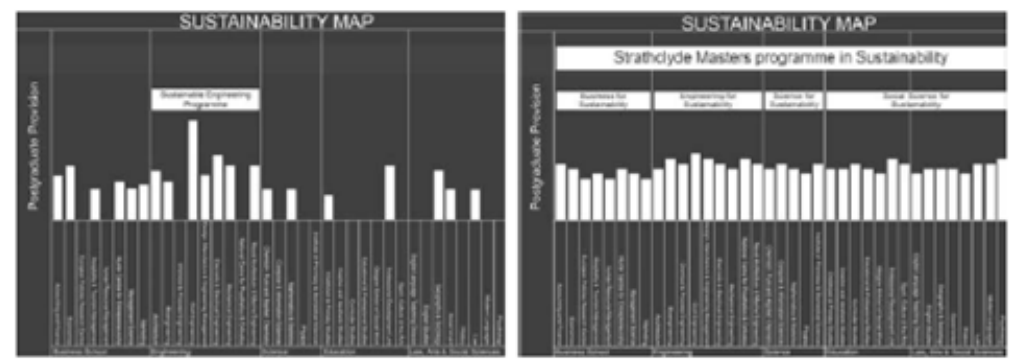

Figure 4: (a) Current Sustainability Maps \& (b) Future Sustainability Map

The following table summarises the objectives stated by the Scottish Government and describes how the University aims to achieve these through the continuation of the three main stages of research as described in the previous sections. 


\begin{tabular}{|c|c|}
\hline Scottish Government Objectives & SMS Actions \\
\hline $\begin{array}{l}\text { Enhance links with local businesses \& } \\
\text { communities }\end{array}$ & $\begin{array}{l}\text { Encouraging direct involvement of local or- } \\
\text { ganisations in curriculum design and develop- } \\
\text { ment \& teaching through live projects etc. }\end{array}$ \\
\hline $\begin{array}{l}\text { Compensate for lack of R \& D undertaken by } \\
\text { business }\end{array}$ & $\begin{array}{l}\mathrm{R} \& \mathrm{D} \text { projects set by industry. Student gains } \\
\text { work experience in live project, expert guest } \\
\text { lectures. Industry gains expert knowledge, } \\
\text { reputation among new graduates, access to } \\
\text { CPD courses. }\end{array}$ \\
\hline Enhance gradate employability & $\begin{array}{l}\text { Foster relationships between student and in- } \\
\text { dustry through live project work \& greater } \\
\text { involvement of both parties in curriculum } \\
\text { development meaning more relevant graduate } \\
\text { skills. }\end{array}$ \\
\hline $\begin{array}{l}\text { Respond to changing workforce skills needs } \\
\& \text { provide flexible learning }\end{array}$ & $\begin{array}{l}\text { Involvement of students and external organ- } \\
\text { isations in curriculum development; interdis- } \\
\text { ciplinary, problem-based, live, group projects } \\
\text { alongside individual dissertations; develop- } \\
\text { ment of student/industry relationship; use of } \\
\text { VLE. }\end{array}$ \\
\hline Integrate ESD into the curriculum & $\begin{array}{l}\text { SMS is platform for interdisciplinary engage- } \\
\text { ment and growth of ESD activity across the } \\
\text { university. Flagship courses complemented } \\
\text { by generic SD modules. }\end{array}$ \\
\hline $\begin{array}{l}\text { Sustain growth in postgraduate student num- } \\
\text { bers \& enhance international academic links }\end{array}$ & $\begin{array}{l}\text { Through enhanced employability \& more } \\
\text { relevant \& flexible course provision }\end{array}$ \\
\hline
\end{tabular}

A draft structure for the SMS programme has also been developed as a version of the successful model which has been running within the Sustainable Engineering since 1999 (Table 4). In this expanded version the aim is to enhance teaching quality and the students' learning experience through an integrated and co-ordinated programme that operates efficiently across the University, drawing on discipline strengths within Faculties to provide an interdisciplinary response to the major challenges presented within the sustainable development agenda. strathclyde's profile as a research-led institution consolidating a reputation for innovation in learning and teaching, building upon a long tradition of strong engagement with government, business, industry and local communities, positions the University well to meet this challenge. The University's aspirations build upon the history of a "place of useful learning" that is both locally grounded and internationally minded. 
Table 4: Draft SMS Programme and Teaching Structure

\begin{tabular}{|c|c|c|}
\hline \multicolumn{3}{|c|}{ (SMS) PROGRAMME STRUCTURE } \\
\hline \multicolumn{3}{|l|}{ Step One: Select Faculty Package } \\
\hline \multicolumn{3}{|c|}{$\begin{array}{l}\text { BUSINESS FOR SUSTAINABILITY } \\
\text { ENGINEERING FOR SUSTAINABILITY } \\
\text { HUMANITIES \& SOCIAL SCIENCE FOR SUSTAINABILITY } \\
\text { SCIENCE FOR SUSTAINABILITY }\end{array}$} \\
\hline \multicolumn{3}{|c|}{ Step Two: Select Specialist Theme with Compulsory Specialist Module(s) } \\
\hline \multicolumn{3}{|c|}{ Step Three: Select University SD Module(s) from list } \\
\hline \multicolumn{3}{|c|}{ Step Four: Select Faculty 'Generic' Module(s) from list } \\
\hline \multicolumn{3}{|c|}{$\begin{array}{l}\text { Step Five: Complete Interdisciplinary Group Project or Select Additional Specialist Mod- } \\
\text { ule(s) }\end{array}$} \\
\hline \multicolumn{3}{|c|}{ Participation in Sustainability Workshops } \\
\hline \multicolumn{3}{|c|}{ Step Six: Complete Individual Project/Dissertation } \\
\hline \multicolumn{3}{|c|}{ (SMS) TEACHING STRUCTURE } \\
\hline September-December & January-April & April-September \\
\hline \multirow[t]{2}{*}{$\begin{array}{l}\text { Specialist Modules } \\
\text { University SD \& Faculty Generic } \\
\text { Modules } \\
\text { Field Trips/Sustainability } \\
\text { Workshops }\end{array}$} & & $\begin{array}{l}\text { Individual Project/ } \\
\text { Dissertation }\end{array}$ \\
\hline & \begin{tabular}{|l|} 
Interdisciplinary Group Project \\
SMS Annual Project Conference
\end{tabular} & \\
\hline
\end{tabular}

\section{Conclusion}

This paper has explored the experience of an initiative taking place within a university in response to the ESD agenda and more specifically how this responds to the objectives set out for universities within the Scottish Government's publications. The SMS vision is given as context for the paper followed by a brief overview which establishes the importance of ESD and the role that universities have to play in the sustainability agenda. A summary of two Scottish Government documents; New Horizons: responding to the challenges of the 21st century (2008) and Learning for Change: Scotland's Action Plan for the Second Half of the UN Decade of Education for Sustainable Development (2010) highlights the relevant key objectives with regards to embedding ESD and responding to the issues it deals with including climate change, changing demographics, economic challenges, growing international competition and changing skill requirements in the workforce. The University of Strathclyde is responding in many ways to the Government's objectives and its achievements as an emerging leader in the field of ESD are introduced as context to research specific to the SMS project. 
The paper highlights the principal conclusions drawn from the three main stages of research undertaken including (i) a review of current thinking in ESD, (ii) a structured consultation programme and (iii) the creation of both a current and future 'sustainability map'. It is agreed that the definition and priorities of SD are complex and multi-layered and the challenges of $\mathrm{SD}$, being inherently holistic, require responses from all disciplines and professions represented within the institution. However, the Sustainability Map has shown that the current level of provision of postgraduate ESD varies greatly across the University. This requires the development of a framework for pan-University, cross disciplinary teaching and the existing Masters Programme in Sustainable Engineering offers a model on which such a framework might be based. The need for knowledge and understanding of the complex issues involved in SD is coupled with the need for practical skills. There is a demand from students and external collaborators for sustainability and its associated interdisciplinary skills to be given more emphasis with the University.

A summary table of Scottish Government objectives and University Actions demonstrates how the SMS intends to respond to key objectives, as identified in the summary section. A draft SMS Programme Structure is then presented which shows how these actions can be practically incorporated into the curriculum. It is intended that the outcomes of this research form the basis for future consultation which will use the same methodology in order to focus on the structural refinement and the academic content of the interdisciplinary programme.

\section{References}

Centre for Sustainable Futures Occasional Paper 3, Getting it Together: Interdisciplinarity and Sustainability in the Higher Education Institution, (CSF, 2009).

Engineering Education for Sustainable Development, European sustainability rankings, Observatory Report, 2008 (EESD, 2008)

Available online: https://www.upc.edu/eesdobservatory/why/reports/EESD_Observer_2008_.pdf

Grierson, D \& Hyland, C, Towards a Framework for University-wide Postgraduate Programmes in Sustainability; International Journal of Interdisciplinary Social Sciences, Volume 5, Issue 2, pp.549-564, 2010. (Grierson, D; Hyland, C, 2010)

Higher Education Academy (HEA), Sustainable Development in Higher Education, Current Practice and Future Developments - A Progress Report for Senior Managers in Higher Education (HEA, Jan 2006)

Higher Education Academy (HEA), Engineering Subject Centre Mini-Project Report, Engineering Education for Sustainable Development - Report of a Delphi Consultation, ISBN 97-8190480-4727 (HEA, Apr 2008)

Higher Education Academy (HEA), Dr Alex Ryan, 2008 Review of Education for Sustainable Development (ESD) in Higher Education in Scotland - Final Report (HEA, Feb 2009)

Higher Education Academy (HEA) http://www.heacademy.ac.uk/scotland/aboutus Last accessed: 21/09/10. Published: 14/08/2009. (HEA, Aug 2009)

Scottish Funding Council (SFC), Corporate Plan 2009 - 2012 (SFC, 2009)

United Nations Development Programme. (2007). The Human Development concept. Available: http://hdr.undp.org/en/humandev/. Last accessed: 01/06/10. Published: 29/10/07 (UNDP, 2007)

UNESCO, Guidelines and Recommendations for Reorienting Teacher Education to Address Sustainability (UNESCO 2005)

UNESCO, Quality Education, Equity and Sustainable Development (UNESCO, Nov 2008)

UNESCO, Review of Contexts and Structures for Education for Sustainable Development 2009 (UNESCO 2009) 
UNESCO, UK National Commission, Education for Sustainable Development in the UK in 2010 (UNESCO, Sep 2010)

United Nations, World Summit on Sustainable Development in Johannesburg, South Africa, declared: United Nations Decade of Education for Sustainable Development (UNDESD, Johannesburg Summit, 2002)

\section{About the Authors}

\section{Dr. David Grierson}

Dr. Grierson is both an architect and academic. He is currently Director of Postgraduate Research and Knowledge Exchange in Architecture and has directed the Postgraduate Programme in Sustainable Engineering at University of Strathclyde Glasgow since 2004. His teaching and research interests are in sustainable architecture and urban design. He is particularly active in the integration of teaching and learning activity across the postgraduate community, and the promotion of knowledge exchange through increased engagement with business, industry, the professions, and other institutions. Dr Grierson is a Fellow of the Higher Education Academy (FHEA) and a visiting professor at Universities in Rome and Florence. His own architectural work has been exhibited at the Royal Academy Exhibition in London and he has gained a number of architectural awards including two Glasgow Institute of Architecture (GIA) Design Awards. He is a recipient of the Sir Rowan Anderson Silver Medal for Architectural Design from th Royal Institute of Architects in Scotland (RIAS).

\section{Claire Hyland}

Claire Hyland graduated from Postgraduate Studies at the University of Strathclyde, Glasgow in 2007. She is currently employed as a Sustainability Research Assistant in the Department of Architecture at Strathclyde supporting Dr. David Grierson in consulting widely on the framework for developing new postgraduate activity in the area of environmental, social, and economic sustainability. Claire's main interests are in sustainable and accessible architecture and urban design, education and graphic design. She is also currently working with a visually impaired $\mathrm{PhD}$ student of Architecture, assisting in his research and image production and gaining experience through tutoring students. Additional projects include working in collaboration with colleagues in creating and designing workshop activities for school children based on sustainable communities (event to be held in the Science Centre, Glasgow as part of the ESRC Festival of Social Science 2010). Previous to her engagement at the university, Claire gained professional experience working in architectural practices both in the Glasgow and Spain, where she experienced a different culture and working methods as well as gaining fluency in the language. 


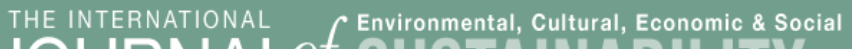

\section{Editors}

Amareswar Galla, The University of Queensland, Brisbane, Australia.

Bill Cope, University of Illinois at Urbana-Champaign, USA.

\section{Editorial Advisory Board}

Shamsul Nahar Abdullah, University of Malaysia Terengganu, Malaysia.

Wan Izatul Asma, University of Malaysia Terengganu, Malaysia.

Dang Van Bai, Ministry of Culture and Information, Vietnam.

Michael Cameron, University of Waikato, Hamilton, New Zealand.

Richard M. Clugston, University Leaders for a Sustainable Future, Washington, USA. John Dryzek, Australian National University, Canberra, Australia.

Dato'Abdul Razak Dzulkifli, Universiti Sains Malaysia, Malaysia.

Robyn Eckersley, University of Melbourne, Melbourne, Australia.

Steven Engelsman, Rijksmuseum voor Volkenkunde, Leiden, The Netherlands.

John Fien, RMIT University, Melbourne, Australia.

Suzanne Grant, University of Waikato, Hamilton, New Zealand.

Steve Hamnett, University of South Australia, Adelaide, Australia.

Paul James, RMIT University, Melbourne, Australia.

Mary Kalantzis, University of Illinois, Urbana-Champaign, USA.

Nik Fuad Nik Mohd Kamil, University of Malaysia Terengganu, Malaysia.

Lily Kong, National University of Singapore, Singapore.

Thangavelu Vasantha Kumaran, University of Madras, Chennai, India.

Jim McAllister, Central Queensland University, Rockhamptom, Australia.

Nik Hashim Nik Mustapha, University of Malaysia Terengganu, Malaysia.

Helena Norberg-Hodge, The International Society for Ecology and Culture (ISEC), UK.

Peter Phipps, RMIT University, Melbourne, Australia.

Koteswara Prasad, University of Madras, Chennai, India.

Behzad Sodagar, University of Lincoln, Brayford Pool, United Kingdom. Judy Spokes, Cultural Development Network, Melbourne, Australia.

Manfred Steger, Illinois State University, Normal, USA; RMIT University, Melbourne, Australia.

Douglas Worts, LEAD Fellow (Leadership for Environment and Development), Toronto, Canada

David Wood, University of Waterloo, Waterloo, Canada.

Lyuba Zarsky, RMIT University, Melbourne, Australia; Tufts University, Medford, USA.

Please visit the Journal website at http://www.Sustainability-Journal.com for further information about the Journal or to subscribe. 


\section{The Sustainability Community}

This is a knowledge community brought together by a common concern for sustainability in an holistic perspective, where environmental, cultural, economic and social concerns intersect. The community interacts through an innovative, annual face-to-face conference, as well as year-round virtual relationships in a weblog, peer reviewed journal and book imprint - exploring the affordances of the new digital media. Members of this knowledge community include academics, researchers, policy makers, public servants, members of government and non-government organisations, consultants, educators and research students.

\section{Conference}

Members of the Sustainability Community meet at the International Conference on Environmental, Cultural, Economic and Social Sustainability, held annually in different locations around the world.

The Conference was held at the University of Waikato, Hamilton, New Zealand in 2011; University of Cuenca, Cuenca, Ecuador in 2010; University of Technology Mauritius, Mauritius in 2009; Universiti Malaysia Terengganu, Kuala Terengganu, Malaysia in 2008; University of Madras, Chennai, India in 2007; Hanoi and Ha Long Bay, Vietnam in 2006; and the University of Hawai'i at Manoa, Island of Oahu, Hawai'i, USA in 2005. In 2012, the Conference will be held at the Robson Square, University of British Columbia, Vancouver, Canada.

Our community members and first time attendees come from all corners of the globe. Intellectually, our interests span the breadth of the various sustainability disciplines and fields of study. The Conference is a site of critical reflection, both by leaders in the field and emerging scholars. Those unable to attend the Conference may opt for virtual participation in which community members can either submit a video and/or slide presentation with voice-over, or simply submit a paper for peer review and possible publication in the Journal.

Online presentations can be viewed on YouTube.

\section{Publishing}

The Sustainability Community enables members to publish through three media. First, by participating in the Sustainability Conference, community members can enter a world of journal publication unlike traditional academic publishing forums - a result of the responsive, non-hierarchical and constructive nature of the peer review process. The International Journal of Environmental, Cultural, Economic and Social Sustainability provides a framework for double-blind peer review, enabling authors to publish into an academic journal of the highest standard.

The second publication medium is through the book series On Sustainability, publishing cutting edge books in print and electronic formats. Publication proposals and manuscript submissions are welcome.

The third major publishing medium is our news blog, constantly publishing short news updates from the Sustainability Community, as well as major developments in the various disciplines of sustainability. You can also join this conversation at Facebook and Twitter or subscribe to our email Newsletter. 


\section{Common Ground Publishing Journals}

\begin{tabular}{|c|c|}
\hline $\begin{array}{l}\text { AGING } \\
\text { Aging and Society: An Interdisciplinary Journal } \\
\text { Website: http://AgingAndSociety.com/journal/ }\end{array}$ & $\begin{array}{c}\text { ARTS } \\
\text { The International Journal of the Arts in Society. } \\
\text { Website: www.Arts-Journal.com }\end{array}$ \\
\hline $\begin{array}{c}\text { BOOK } \\
\text { The International Journal of the Book } \\
\text { Website: www.Book-Journal.com }\end{array}$ & $\begin{array}{c}\text { CLIMATE CHANGE } \\
\text { The International Journal of Climate Change: } \\
\text { Impacts and Responses } \\
\text { Website: www.Climate-Journal.com }\end{array}$ \\
\hline $\begin{array}{c}\text { CONSTRUCTED ENVIRONMENT } \\
\text { The International Journal of the } \\
\text { Constructed Environment } \\
\text { Website: www.ConstructedEnvironment.com/journal }\end{array}$ & $\begin{array}{c}\text { DESIGN } \\
\text { Design Principles and Practices: } \\
\text { An International Journal } \\
\text { Website: www.Design-Journal.com }\end{array}$ \\
\hline $\begin{array}{c}\text { DIVERSITY } \\
\text { The International Journal of Diversity in } \\
\text { Organizations, Communities and Nations } \\
\text { Website: www.Diversity-Journal.com }\end{array}$ & $\begin{array}{l}\text { FOOD } \\
\text { Food Studies: An Interdisciplinary Journal } \\
\text { Website: http://Food-Studies.com/journal/ }\end{array}$ \\
\hline $\begin{array}{c}\text { GLOBAL STUDIES } \\
\text { The Global Studies Journal } \\
\text { Website: www.GlobalStudiesJournal.com }\end{array}$ & $\begin{array}{c}\text { HEALTH } \\
\text { The International Journal of Health, } \\
\text { Wellness and Society } \\
\text { Website: www.HealthandSociety.com/journal }\end{array}$ \\
\hline $\begin{array}{c}\text { HUMANITIES } \\
\text { The International Journal of the Humanities } \\
\text { Website: www.Humanities-Journal.com }\end{array}$ & $\begin{array}{c}\text { IMAGE } \\
\text { The International Journal of the Image } \\
\text { Website: www.Onthelmage.com/journal }\end{array}$ \\
\hline $\begin{array}{l}\text { LEARNING } \\
\text { The International Journal of Learning. } \\
\text { Website: www.Learning-Journal.com }\end{array}$ & $\begin{array}{c}\text { MANAGEMENT } \\
\text { The International Journal of Knowledge, } \\
\text { Culture and Change Management. } \\
\text { Website: www.Management-Journal.com }\end{array}$ \\
\hline $\begin{array}{c}\text { MUSEUM } \\
\text { The International Journal of the Inclusive Museum } \\
\text { Website: www.Museum-Journal.com }\end{array}$ & $\begin{array}{c}\text { RELIGION AND SPIRITUALITY } \\
\text { The International Journal of Religion and } \\
\text { Spirituality in Society } \\
\text { Website: www.Religion-Journal.com }\end{array}$ \\
\hline $\begin{array}{c}\text { SCIENCE IN SOCIETY } \\
\text { The International Journal of Science in Society } \\
\text { Website: www.ScienceinSocietyJournal.com }\end{array}$ & $\begin{array}{c}\text { SOCIAL SCIENCES } \\
\text { The International Journal of Interdisciplinary } \\
\text { Social Sciences } \\
\text { Website: www.SocialSciences-Journal.com }\end{array}$ \\
\hline $\begin{array}{c}\text { SPACES AND FLOWS } \\
\text { Spaces and Flows: An International Journal of } \\
\text { Urban and ExtraUrban Studies } \\
\text { Website: www.SpacesJournal.com }\end{array}$ & $\begin{array}{c}\text { SPORT AND SOCIETY } \\
\text { The International Journal of Sport and Society } \\
\text { Website: www.sportandsociety.com/journal }\end{array}$ \\
\hline $\begin{array}{c}\text { SUSTAINABILITY } \\
\text { The International Journal of Environmental, Cultural, } \\
\text { Economic and Social Sustainability } \\
\text { Website: www.Sustainability-Journal.com }\end{array}$ & $\begin{array}{c}\text { TECHNOLOGY } \\
\text { The International Journal of Technology, } \\
\text { Knowledge and Society } \\
\text { Website: www.Technology-Journal.com }\end{array}$ \\
\hline $\begin{array}{c}\text { UBIQUITOUS LEARNING } \\
\text { Ubiquitous Learning: An International Journal } \\
\text { Website: www.ubi-learn.com/journal/ }\end{array}$ & $\begin{array}{l}\text { UNIVERSITIES } \\
\text { Journal of the World Universities Forum } \\
\text { Website: www.Universities-Journal.com }\end{array}$ \\
\hline
\end{tabular}

